\title{
The Effects of Portfolio Purchasing on Scientific Subject Collections
}

\author{
Sarah Anne Murphy
}

\begin{abstract}
A citation analysis was conducted to understand how the purchase of journal portfolios supports the research of faculty in the life, medical, physical and applied sciences and influences collections at The Ohio State University. Of the 253,604 citations from 6,815 articles reviewed, faculty cited 2,407 journal titles ten or more times. Results indicated that less than 50 percent of the titles listed for faculty in the Colleges of Dentistry, Nursing, Pharmacy, and Veterinary Medicine were acquired through a portfolio. A discussion questioning the value of the portfolio purchase follows, with the author concluding that journal portfolios are contributing to the normalization of library collections.
\end{abstract}

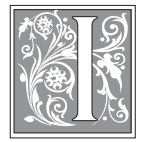

$n$ recent years, several studies have mapped the literature of medical disciplines to identify core journals in their respective fields. ${ }^{1}$ Based on the Bradford distribution, these studies demonstrated that the bulk of cited literature in any discipline is published in a core number of journals. As research libraries move toward purchasing the portfolios of science, technology, and medicine (STM) publishers' journals, similar studies mapping the citation patterns of STM faculty within their respective institutions may prove useful for evaluating the impact or effectiveness of such purchases.

High-profile exits from portfolio purchasing agreements in the last five years have highlighted the benefits and detractions of portfolio purchasing for research institutions. ${ }^{2}$ Cornell University cancelled its portfolio purchase agreement with Elsevier to regain the financial flexibility necessary to acquire other more frequently used titles published by nonprofit societies. ${ }^{3}$ Other institutions, like University of Wisconsin, Madison, have avoided the portfolio altogether, claiming they "weaken the power of librarians and consumers to influence scholarly communication systems." ${ }^{4}$ Meanwhile, large purchasing consortiums like OhioLINK have enthusiastically embraced the portfolio purchase on behalf of its members, arguing that the benefits of acquiring more titles than any individual library could have obtained on its own outweigh the premium paid for the portfolio. ${ }^{5}$ One question that deserves exploration, however, is whether the research institution truly benefits from purchasing the entire catalog of a publisher's journal offerings,

Sarah Anne Murphy is Coordinator of Research and Reference Services and Associate Professor at The Ohio State University; e-mail: murphy.465@osu.edu. The author gratefully acknowledges the following individuals at The Ohio State University Libraries for their assistance in the preparation of this article: Tschera Harkness Connell, Head, Scholarly Resources Integration Department; Celeste Feather, Assistant to the Library Director; and Susan Logan, Head (emeritus), Food, Agricultural, and Environmental Sciences Library. The author would also like to thank Miriam Utter for proofreading the final draft. 
as a significant portion of a portfolio includes titles not used by the institution's faculty. Further, could a consequence of the portfolio purchase be the normalizing of research library collections? Are some disciplines disproportionately supported by portfolio purchasing agreements?

Citation analysis may offer an answer to these and other questions. While the method in itself is not without limitations, it does provide some indication of the literature that faculty consults for research in their field. ${ }^{6}$ Using the Bradford distribution as a tool to map the literature that faculty in life, medical, and physical sciences cite, a research library may obtain a better understanding of the journals that research faculty use regularly at their institution and determine the true cost-effectiveness of a portfolio purchase. Based on Samuel C. Bradford's Law of Journal Scatter, the heuristic is useful for demonstrating that a core number of journals generate the greatest number of citations in any given field. ${ }^{7}$

The Ohio State University Libraries currently offers access to more than 10,000 electronic journals to students, faculty, and staff of the institution. Of these journals, just over 6,000 are procured through OhioLINK, a consortium of Ohio's college and university libraries that is funded partially by the state government and partially by member institutions. The remaining titles are purchased both electronically and in print using funding designated for specific subject disciplines. The study reported in this paper continues and expands upon a previous study, conducted by the author, which examined the effects of portfolio purchasing on a specialized subject collection at The Ohio State University. ${ }^{8}$ This study reports on a citation analysis that mapped the citation patterns of all faculty in the life, medical, physical, and applied sciences at The Ohio State University. The purpose of the study was to obtain a better understanding of how the consortium-negotiated portfolio purchase supports faculty research and influences the development of The Ohio
State University Libraries life, medical, physical, and applied science collections.

\section{Methods}

A list of journal articles published between the years 2003 and 2005 by faculty in the life, medical, physical, and applied sciences was generated using ISI's Science Citation Index. Publications were then assigned to one of the university colleges listed in Appendix A, with multidisciplinary works assigned to the college of the first Ohio State University faculty author listed. Cited references for each publication were then pulled using Science Citation Index, coded for the appropriate university college, and sorted to separate cited books, conference proceedings, thesis, and "other" items from cited articles. If the information provided by ISI did not clearly indicate the nature of the cited reference, the author assigned the "other" category.

Cited journal references for each college were then analyzed to determine the number of times faculty cited a specific journal. A ranked list of cited reference counts was created for each college and organized in descending order. A second "master list" of all journals cited by Ohio State faculty in the life, medical, physical, and applied sciences was then created by combining the lists of the individual colleges. Journals cited fewer than 10 times on each list were then removed from each list, as the majority of these 17,827 titles were cited only once over the three-year period. The Bradford distribution was calculated by dividing the total number of citations for each list by three to determine the three groups or zones of cited references. ${ }^{9}$ Zone 1 represented the core journals cited by faculty in each college and for the "master list" the core life, medical, physical, and applied sciences journals cited by faculty at The Ohio State University. Zone 2 represented more secondary titles for these faculty, while Zone 3 represented those journals cited least frequently. 


\begin{tabular}{|c|c|c|c|c|c|c|c|c|c|c|c|}
\hline & Nun & ber & f Jour & nal Ti & $\begin{array}{l}\text { ABLE } \\
\text { es Cit }\end{array}$ & $\begin{array}{l}1 \\
\text { d by } F\end{array}$ & acult & y by & College & & \\
\hline & 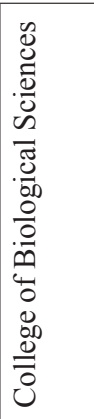 & 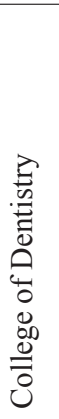 & 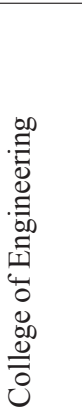 & 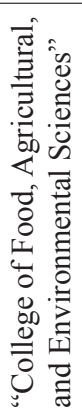 & 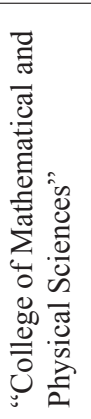 & 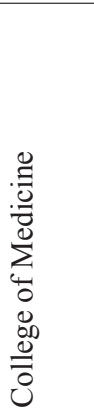 & 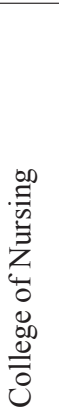 & $\begin{array}{l}\text { ह } \\
0 \\
0 \\
0 \\
0 \\
0 \\
0 \\
4 \\
0 \\
0 \\
0 \\
0 \\
0 \\
0 \\
0\end{array}$ & 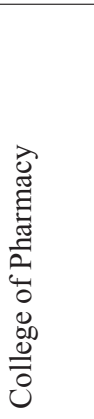 & 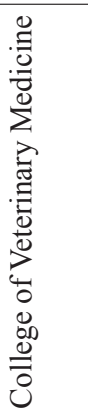 & 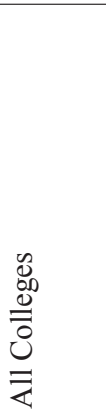 \\
\hline $\begin{array}{l}\text { "Journals } \\
\text { Cited } 10 \text { or } \\
\text { more times" }\end{array}$ & 290 & 75 & 422 & 379 & 511 & 791 & 17 & 27 & 149 & 275 & 2,407 \\
\hline $\begin{array}{l}\text { "Journals } \\
\text { Cited } 9 \text { or } \\
\text { fewer times" }\end{array}$ & 2,079 & 715 & 2,911 & 2,509 & 3,012 & 2,959 & 360 & 202 & 1,334 & 1,969 & 18,579 \\
\hline Total & 2,369 & 790 & 3,333 & 2,888 & 3,523 & 3,750 & 377 & 229 & 1,483 & 2,244 & 20,986 \\
\hline
\end{tabular}

Publisher information was added to the lists to determine how the library procured access to the title: 1 ) through OhioLINK, the largest provider of portfolio-acquired content at The Ohio State University; 2) by purchasing an independent print subscription; or 3) by purchasing an independent electronic subscription. This information was then compared to Ohio State's FY06 expenditures for independently purchased journals and OhioLINK-negotiated journal portfolios. Since the nature of portfolio purchasing makes it difficult to determine the cost-effectiveness of an individual journal subscription, a list of titles procured through OhioLINK-sponsored portfolio purchases was reviewed using subject headings listed in Ulrich's Periodicals Directory, to remove humanities and social sciences titles from the list. ${ }^{10}$ Ohio State's contribution to OhioLINKnegotiated portfolio purchases was then adjusted by removing the percentage of out-of-scope titles to reflect expenditures on scientific information. The actual price of the scientific titles provided through the OhioLINK portfolio purchases was then gathered using a combination of
EBSCO's Librarian's Handbook 2006-2007 and Ulrich's Periodicals Directory. ${ }^{11}$ Prices reported for FY07 in Ulrich's Periodicals Directory were discounted by 6 percent to account for FY06 inflation. These activities were designed to determine what Ohio State would have actually paid if the university had purchased each title from these publishers' portfolios independently.

\section{Results}

A total of 253,604 citations from 6,815 articles published by faculty in the life, medical, physical, and applied sciences were gathered for analysis. Of these 253,604 citations, 200,872 represented the 2,407 journal titles cited by faculty in all of the colleges at least 10 or more times over the three-year period (table 1). (The Bradford distribution for these cited references is listed in figure 1 and table 2.) Only 1.9 percent $(n=45 / 2,407)$ of titles cited more than 10 times by faculty were listed in Zone 1 of the distribution. This represented the core journals cited by Ohio State science faculty. Of the journals in Zone 1, 35.5 percent $(n=16 / 45)$ were purchased through an OhioLINK-negotiated 


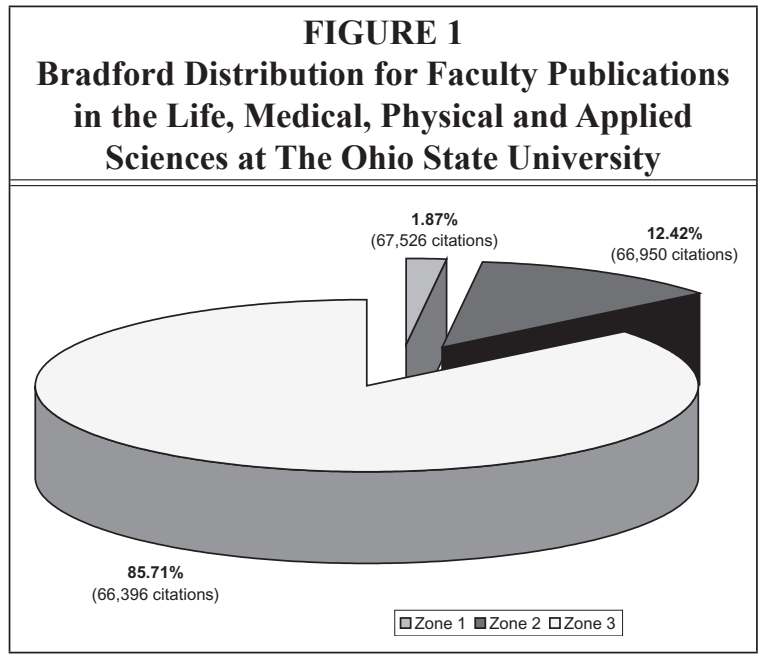

acquired through an OhioLINK-negotiated portfolio purchase. The remaining current subscriptions were either available only in print $(7.0 \%, \mathrm{n}=168 / 2,407)$ or were purchased electronically by the libraries for faculty $(26.3 \%, n=634 / 2,407)$.

College of Medicine faculty cited references from the largest number of journal titles $(n=791)$, followed by the College of Mathematical and Physical Sciences $(n=511)$ and the College of Engineering ( $n$ $=422)$. For the College of

portfolio purchase, while 62.2 percent $(\mathrm{n}=$ 28/45) were procured individually by The Ohio State University Libraries (figure 2). While none were available only in print, it is important to note that the library was required to maintain print subscriptions for five of the titles, as electronic access was only available following a four- to twelve-month embargo. Overall, 52.0 percent $(n=1,251 / 2,407)$ of the cited journal titles in Zone 1, 2, and 3 were
Engineering, 62.0 percent $(n=18)$ of the journals listed in Zone 1 of the Bradford distribution were obtained through a portfolio purchase, while 85.7 percent $(n=6 / 7)$ of the titles listed in Zone 1 of the College of Mathematical and Physical Sciences were acquired through this means. In contrast, less than 40 percent of the journals included in Zone 1 for the Colleges of Biological Sciences $(n=4 / 12)$, Food, Agricultural, and Environmental

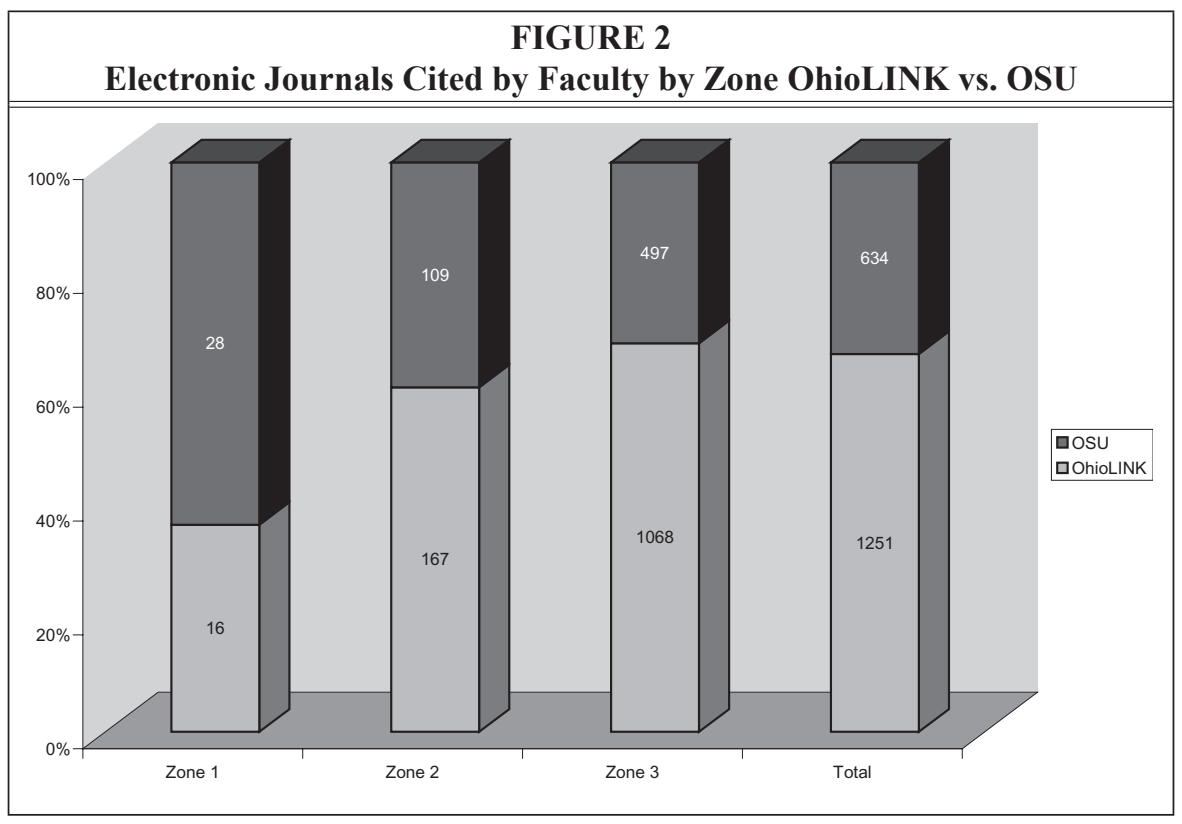


TABLE 2

Bradford Distribution for Faculty Publications in the Life, Medical, Physical and Applied Sciences at The Ohio State University

\begin{tabular}{|c|c|c|c|c|c|c|c|c|c|c|c|}
\hline & 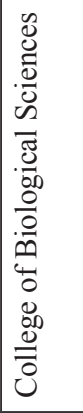 & 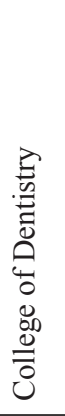 & 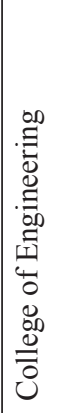 & 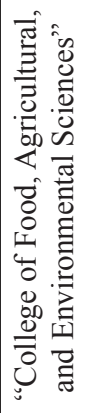 & 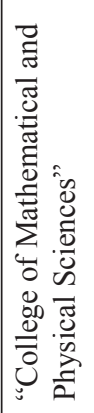 & 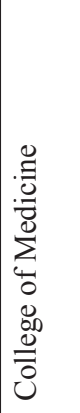 & 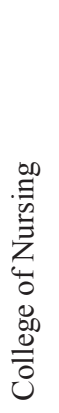 & 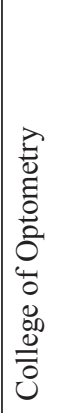 & 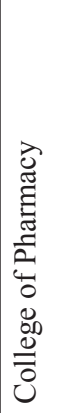 & 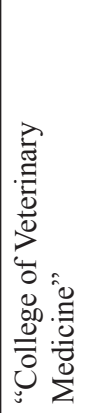 & 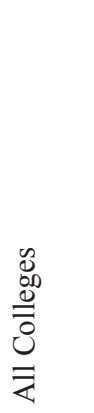 \\
\hline \multicolumn{12}{|l|}{ Zone 1} \\
\hline OhioLINK & 4 & 3 & 18 & 3 & 6 & 3 & 0 & 2 & 3 & 3 & 16 \\
\hline OSU* & 8 & 2 & 8 & 16 & 1 & 18 & 4 & 3 & 9 & 10 & 28 \\
\hline Print & 0 & 1 & 0 & 0 & 0 & 0 & 0 & 0 & 0 & 1 & 0 \\
\hline Other** & 0 & 0 & 3 & 0 & 0 & 0 & 0 & 0 & 0 & 0 & 1 \\
\hline TOTAL & 12 & 6 & 29 & 19 & 7 & 21 & 4 & 5 & 12 & 14 & 45 \\
\hline \multicolumn{12}{|l|}{ Zone 2} \\
\hline OhioLINK & 30 & 5 & 51 & 40 & 28 & 58 & 1 & 4 & 18 & 17 & 167 \\
\hline OSU* & 23 & 9 & 24 & 23 & 9 & 46 & 4 & 1 & 18 & 25 & 109 \\
\hline Print & 1 & 3 & 3 & 6 & 1 & 2 & 0 & 0 & 1 & 6 & 13 \\
\hline Other** & 0 & 1 & 7 & 3 & 0 & 1 & 1 & 3 & 0 & 0 & 10 \\
\hline TOTAL & 54 & 18 & 85 & 72 & 38 & 107 & 6 & 8 & 37 & 48 & 299 \\
\hline \multicolumn{12}{|l|}{ Zone 3} \\
\hline OhioLINK & 155 & 22 & 154 & 167 & 261 & 351 & 4 & 5 & 47 & 99 & 1,068 \\
\hline OSU* & 40 & 18 & 94 & 61 & 111 & 219 & 3 & 5 & 43 & 74 & 497 \\
\hline Print & 8 & 6 & 21 & 17 & 31 & 41 & 0 & 2 & 3 & 19 & 155 \\
\hline Other** & 21 & 5 & 39 & 43 & 63 & 52 & 0 & 2 & 7 & 21 & 343 \\
\hline TOTAL & 224 & 51 & 308 & 288 & 466 & 663 & 7 & 14 & 100 & 213 & 2,063 \\
\hline $\begin{array}{l}\text { Grand } \\
\text { Total }\end{array}$ & 290 & 75 & 422 & 379 & 511 & 791 & 17 & 27 & 149 & 275 & 2,407 \\
\hline \multicolumn{12}{|c|}{ *Includes titles with 4-24 month embargos. } \\
\hline & & & & & & & & & & & \\
\hline
\end{tabular}


Sciences $(n=3 / 19)$, Medicine $(n=3 / 21)$, Nursing $(n=2 / 5)$, Pharmacy $(n=3 / 12)$, and Veterinary Medicine $(n=3 / 14)$ were procured through a portfolio purchase.

While nearly half of the journal titles cited in Zones 1 and 2 for the Colleges of Biological Sciences, Medicine, and Food, Agricultural, and Environmental Sciences were acquired through a portfolio, access to 75.5 percent $(n=34 / 45)$ of the titles cited by faculty in the Colleges of Mathematical and Physical Sciences and 60.5 percent $(69 / 114)$ of titles cited by faculty in the College of Engineering was provided by a portfolio in these same zones. In the Colleges of Dentistry, Nursing, Pharmacy, and Veterinary Medicine, access to more than 50 percent of the titles cited in all zones were procured by the Ohio State University Libraries and not directly provided through an OhioLINK-negotiated portfolio purchase.

\begin{tabular}{|c|c|c|c|c|c|}
\hline \multicolumn{6}{|c|}{$\begin{array}{c}\text { TABLE } 3 \\
\text { Top } 50 \text { Journals Cited }\end{array}$} \\
\hline Cited Work & $\begin{array}{c}\text { No. of } \\
\text { Citations }\end{array}$ & $\begin{array}{c}\text { OSU/ } \\
\text { OhioLINK }\end{array}$ & Cited Work & $\begin{array}{c}\text { No. of } \\
\text { Citations }\end{array}$ & $\begin{array}{c}\text { OSU/ } \\
\text { OhioLINK }\end{array}$ \\
\hline Astrophys $J$ & 4,815 & OSU & J Clin Oncol & 975 & OSU \\
\hline J Biol Chem & 4,758 & OSU & J Dairy Sci & 912 & OSU \\
\hline P Natl Acad Sci USA & 4,098 & OSU & J Exp Med & 863 & OSU \\
\hline Science & 3,396 & OSU & Astron J & 860 & OSU \\
\hline Phys Rev Lett & 3,032 & OhioLINK & Nucleic Acids Res & 806 & OhioLINK \\
\hline Nature & 2,966 & OSU & Oncogene & 803 & OSU \\
\hline Phys Rev D & 2,941 & OhioLINK & Gene Dev & 769 & OSU \\
\hline J Am Chem Soc & 2,348 & OhioLINK & J Mol Biol & 748 & OhioLINK \\
\hline Blood & 2,002 & OSU & Infect Immun & 734 & OSU \\
\hline Phys Lett B & 1,988 & OhioLINK & J Cell Biol & 734 & OSU \\
\hline Cancer Res & 1,878 & OSU & Lancet & 730 & OhioLINK \\
\hline Cell & 1,766 & OhioLINK & \multirow{2}{*}{$\begin{array}{l}\text { Appl Environ } \\
\text { Microb }\end{array}$} & \multirow[t]{2}{*}{710} & \multirow[t]{2}{*}{ OSU } \\
\hline J Chem Phys & 1,579 & OhioLINK & & & \\
\hline J Immunol & 1,424 & OSU & Appl Phys Lett & 696 & OhioLINK \\
\hline Nucl Phys B & 1,395 & OhioLINK & Soil Sci Soc Am J & 691 & OSU \\
\hline New Engl J Med & 1,367 & OSU & J Neurosci & 686 & OSU \\
\hline J Virol & 1,337 & OSU & J Am Vet Med Assoc & 682 & OSU \\
\hline Biochemistry-US & 1,306 & OhioLINK & $J$ Clin Invest & 670 & OSU \\
\hline $\begin{array}{l}\text { Mon Not R Astron } \\
\text { Soc }\end{array}$ & 1,220 & OhioLINK & $\begin{array}{l}\text { Biochem Bioph Res } \\
\text { Co }\end{array}$ & 630 & OhioLINK \\
\hline Am J Physiol & 1,178 & OSU & Nat Genet & 624 & OSU \\
\hline$E M B O J$ & 1,150 & OSU & JAMA: J Am Med & 620 & OhioLINK \\
\hline Astron Astrophys & 1,132 & OSU & Assoc & & \\
\hline Mol Cell Biol & 1,106 & OSU & Am J Vet Res & 601 & OSU \\
\hline Phys Rev B & 1,031 & OhioLINK & Cancer & 600 & $\mathrm{OSU}$ \\
\hline J Bacteriol & 999 & OSU & Circulation & 592 & OSU \\
\hline Nucl Instrum Meth A & 991 & OhioLINK & Inorg Chem & 576 & OhioLINK \\
\hline
\end{tabular}


A review of Ohio State's total expenditures on life, medical, physical, and allied science titles revealed that roughly 70 percent is dedicated to the support of OhioLINK-negotiated portfolio purchases. ${ }^{12}$ Without OhioLINK, Ohio State would have paid 61.4 percent more to purchase each individual title included in the portfolios. An examination of titles listed in Zones 1, 2, and 3 of the "master list," however, indicates that Ohio State would have only paid 30.0 percent more for titles cited more than 10 times by faculty over the three-year period examined. If titles cited more than 15 times by faculty are examined, Ohio State only paid a 8.9 percent premium for the portfolio content.

\section{Discussion}

The question remains whether the additional content provided by a portfolio purchase is truly worth the investment. While arguments for these packages note that libraries gain access to journals previously not owned, the structure of portfolio contracts, where prices are based on the institution's historical subscription levels, inhibit libraries' ability to purchase content from smaller publishers who often have higher-quality journals to offer. Jeon Doh-Shin and Domenico Menicucci view the site license as an unforeseen cost of the shift to electronic publishing. Social welfare decreases with the portfolio purchase as bundling both softens competition from books and "has an indirect effect of negative pecuniary externalities on all other publishers."13 Thus, a side effect of portfolio purchasing is that the library commits less money to books and the journals of other publishers.

Indeed, at Ohio State, nearly 70 percent of adjusted expenditures on life, medical, physical, and allied science titles are committed to supporting OhioLINK-negotiated portfolios of large commercial publishers. Of the top 50 titles cited by Ohio State faculty, the majority were purchased by Ohio State $(62.0 \%)$, whereas OhioLINK titles represented 64.7 percent of the adjusted cost (table 3). The Colleges of Math- ematical and Physical Sciences and the College of Engineering disproportionately benefited from the portfolio purchase, at least for the core journals cited by faculty in Zones 1 and 2. Ohio State's commitment to the portfolio does affect subject areas not typically represented by large commercial publishers. Less than 50 percent of the titles cited ten or more times by faculty in the College of Dentistry, Nursing, Pharmacy, and Veterinary Medicine were provided by publisher portfolios. Such information is not surprising, considering the number of dental, pharmacy, and veterinary medicine schools both in Ohio and the United States. Much of the research in these disciplines is reported in the journals of small societies or publishers. Further, a large research university like Ohio State provides opportunities for research in many niche subject areas, typically not supported by the smaller research institution. This may explain why roughly 50 percent of the journals represented in Zones 1 and 2 for the Colleges of Biological Sciences, Medicine, and Food, Agricultural, and Environmental Sciences were provided via the portfolio.

Aaron Edlin and Daniel Rubinfeld have characterized the "Big Deal" as an anticompetitive strategic barrier, which inhibits a smaller publisher's ability to compete fairly in the open market. ${ }^{14}$ Competition has moved from individual journals to large bundles of journals, especially as libraries achieve little savings by canceling individual titles in a Big Deal portfolio contract. If a small publisher introduces a new journal title, librarians do not have the flexibility to cancel a journal acquired through a portfolio to redirect funds to the purchase of a new title, even if the new title may be more relevant or valued by the institution's faculty. Further, it is difficult to justify spending an additional $\$ 1,000$ to purchase another title in a given subject area, when ten titles in that same subject area are already provided via the portfolio, even if three of these ten titles may be of lower quality. Proportionate savings cannot be guaranteed by 
canceling these titles. Meanwhile, as more and more libraries purchase portfolios of journal titles, library collections become normalized. The lust to obtain access to more journals through a bundled package than the library could subscribe to individually comes at the expense of the ability to purchase unique, higher-quality journals that are often published by nonprofit academic societies and better support faculty research interests and needs. This standardization of library collections has long-term implications for the entire scholarly communication process.

With the advent of portfolio purchasing, a new question to ask, however, is whether the threat of returning to à la carte pricing is truly a threat. Or, stated another way, is the library truly getting a great deal through the "Big Deal"? Commercial prices continue to outpace inflation, even as there are no significant differences in presentation or peer review between commercial and noncommercial journals, and noncommercial journals are cited more..$^{15}$ The nature of bundling, however, makes it difficult for the library to evaluate the true value of the portfolio purchase. Ohio State pays somewhere between an $8.9 \%-30.0 \%$ premium to maintain access to the 3,813 titles representing 75.4 percent of the OhioLINK portfolio, which were not cited by faculty more than 10 times over the 2003-2005 period. This premium could have been directed toward higher-use and higherquality journals, books, or other formats, which the university libraries must forego to direct funds toward the portfolio purchase.

\section{Conclusion}

Mapping the citation patterns of faculty does provide valuable information to evaluate the cost-effectiveness of journal portfolios. The premium paid to maintain access to the 75.4 percent of titles in the portfolio cited infrequently or not at all by faculty should be reconsidered. Rather than contributing to the normalizing of library collections by supporting the strategic positioning of commercial publishers, large research libraries may respond better to the needs of all faculty, especially those conducting research in smaller fields, by returning to à la carte purchasing.

\section{Appendix A}

- College of Biological Sciences 1

- College of Dentistry 1

- College of Engineering 1

- excluding the Knowlton School of Architecture 1

- College of Food, Agricultural, and Environmental Sciences

- excluding the Department of Agricultural, Environmental, \& Development Economics; the Agricultural Technical Institute; and the Department of Human \& Community Resource Development

- College of Mathematical and Physical Sciences 1

- College of Medicine 1

- College of Optometry 1

- College of Pharmacy 1

- College of Veterinary Medicine 1 


\section{Notes}

1. Barbara F. Schloman, "Mapping the Literature of Allied Health: Project Overview," Bulletin of the Medical Library Association 85, no. 3 (1997): 271-77; Barbara F. Schloman, "Mapping the Literature of Health Education," Bulletin of the Medical Library Association 85, no. 3 (1997): 278-83; "Mapping the Literature of Respiratory Therapy," Bulletin of the Medical Library Association 85, no. 3 (1997): 293-96; Judy F. Burnham, "Mapping the Literature of Radiologic Technology," Bulletin of the Medical Library Association 85, no. 3 (1997): 289-92; Barbara M. Walcott, "Mapping the Literature of Diagnostic Medical Sonography," Bulletin of the Medical Library Association 87, no. 3 (1999): 287-91; Aida M. Smith, "Mapping the Literature of Dietetics," Bulletin of the Medical Library Association 87, no. 3 (1999): 292-97; Kathryn L. Reed, "Mapping the Literature of Occupational Therapy," Bulletin of the Medical Library Association 87, no. 3 (1999): 298-304; Sara A. Hook and Crystal F. Wagner, "Mapping the Literature of Dental Assisting," Bulletin of the Medical Library Association 87, no. 3 (1999): 277-82; Ardis Haaland, "Mapping the Literature of Dental Hygiene," Bulletin of the Medical Library Association 87, no. 3 (1999): 283-86; Sheryl R. Stevens, "Mapping the Literature of Cytotechnology," Bulletin of the Medical Library Association 88, no. 2 (2000): 172-77; Francis A. Delwiche, "Mapping the Literature of Clinical Laboratory Science," Journal of the Medical Library Association: JMLA 91, no. 3 (2003): 303-10; Jill Crawley-Low, "Bibliometric Analysis of the American Journal of Veterinary Research to Produce a List of Core Veterinary Medicine Journals," Journal of the Medical Library Association: JMLA 94, no. 4 (2006): 430-34.

2. Charles Goldsmith, "Reed Elsevier Feels Resistance to Web Pricing," Wall Street JournalEastern Edition, Jan. 19, 2004; Nancy J. Gibbs, “Walking Away from the 'Big Deal': Consequences and Achievements," Serials 18 (2005): 89-94.

3. Cornell Faculty Senate, "Resolution Regarding the University Library's Policies on Serials Acquisitions, with Special Reference to Negotiations with Elsevier," available online from www.library.cornell.edu/scholarlycomm/resolution2.htm [Accessed 13 March 2007]; Ellen Finnie Duranceau, "Cornell and the Future of the Big Deal: An Interview with Ross Atkinson," Serials Review 30, no. 2 (2004): 127-30.

4. Kenneth Frazier, "The Librarians' Dilemma: Contemplating the Costs of the "Big Deal" Computer File," D-Lib Magazine 7, no. 3 (2001). Available online from www.dlib.org/dlib/march01/ frazier/03frazier.html. [Accessed 13 March 2007].

5. Tom Sanville et al., "Letter to the Editor," D-Lib Magazine 7, no. 4 (2001). Available online from www.dlib.org/dlib/april01/04letters.html\#SANVILLE. [Accessed 13 March 2007].

6. Janne S. Kotiaho, "Ethical Considerations in Citing Scientific Literature and Using Citation Analysis in Evaluation of Research Performance," Journal of Information Ethics 11, no. 2 (2002): 10-16; Michael Callaham, Robert L. Wears, and Ellen Weber, "Journal Prestige, Publication Bias, and Other Characteristics Associated with Citation of Published Studies in Peer-Reviewed Journals," JAMA: The Journal of the American Medical Association 287, no. 21 (2002): 2847-50.

7. Samuel Clement Bradford, Documentation (Washington, D.C.: Public Affairs Press, 1950).

8. Sarah Anne Murphy, "The Effects of Portfolio Purchasing on a Specialized Subject Collection," Journal of the Medical Library Association 95, no. 1 (2007): 9-13.

9. Bradford, Documentation.

10. Ulrich's Periodicals Directory (New Providence, N.J.: R.R. Bowker, 2001).

11. Librarians' Handbook. (Birmingham, Ala.: EBSCO Subscription Services, 2006).

12. For actual dollar figures, please contact the author.

13. Doh-Shin Jeon and Domenico Menicucci, "Bundling Electronic Journals and Competition among Publishers," Journal of the European Economic Association 4 (2006): 1038-83.

14. Aaron S. Edlin and Daniel L. Rubinfeld, "Exclusion or Efficient Pricing? The 'Big Deal' Bundling of Academic Journals," Antitrust Law Journal 72 (2004): 119-57. 


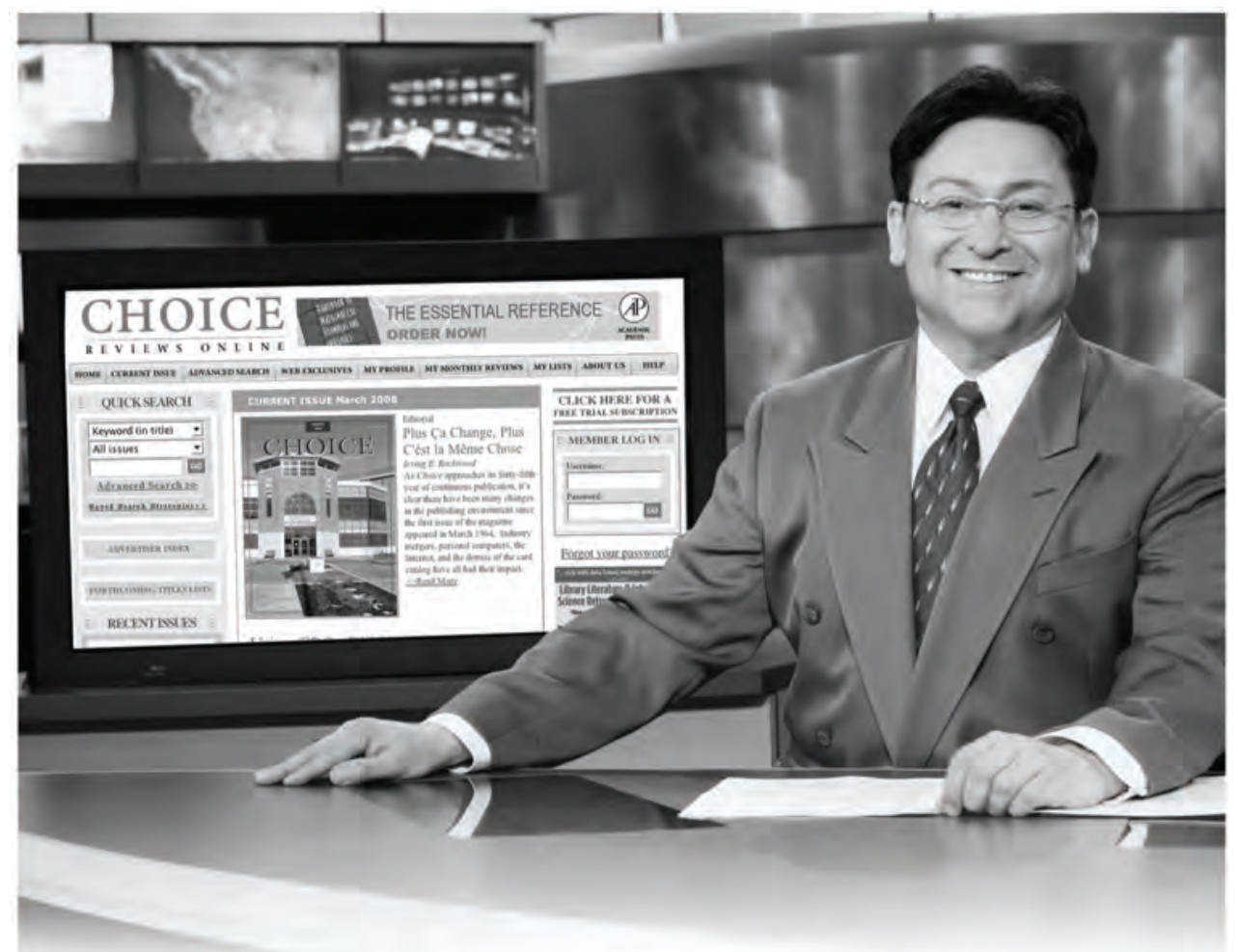

\section{See What People Are Saying About CHOICE REVIEWS ONLINE...}

"The advanced search on Choice Reviews Online is amazing!"

"I rely very heavily on Choice Reviews Online for my own library and book orders - they are the best resource out there."

"Choice Reviews Online is great! It really helps me make decisions about what to buy or recommend."

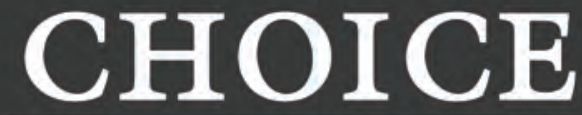

R E V I E W S O N L I N E
- The Perfect Companion to the CHOICE Print Subscription

- Access to Over 125,000 CHOICE Reviews

- Download, Print, or E-mail Search Results

- Ability to Create a Customized Profile

- Create, Save, and E-mail Lists

- Search All CHOICE Content

- View Exclusive Online Material

To learn more about Choice Reviews Online, visit us at www.cro2info.org or sign up for a free 60-day trial at www.cro2.org 